\title{
Multidisciplinary Approach to the Management of Extensive Dermato-fibro-sarcomas Involving the Chest Wall
}

\author{
Wanjala F. Nangole ${ }^{1, \oplus} \quad$ M. Muhinga ${ }^{1}$ \\ ${ }^{1}$ Department of Surgery, University of Nairobi, Nairobi, Kenya
}

Address for correspondence Wanjala F Nangole, MMed (Surg), Department of Surgery, University of Nairobi, Nairobi, P.O. Box 221200202, Kenya (e-mail: nangole2212@gmail.com).

Indian J Plast Surg:2021;54:82-85.

\begin{abstract}
Keywords

- Dermato-fibro-

sarcoma

- chest wall

- multidisciplinary approach

Dermato-fibro-sarcomas are known for high-recurrence rates. The gold standard of management is surgical excision with clear margins. Such margins on the chest results in large defects which require complex reconstructive procedures. We report a case series of patients managed by a multidisciplinary team with good outcomes. A total of 12 patients with extensive dermato-fibro-sarcoma of the anterior chest wall were treated over a period of 5 years in our setting. The age range was 25 to 54 years. Skeletal defects were reconstructed with Prolene mesh and methyl acrylate cement in 10 of the 12 patients. Pedicle flaps were used in nine patients. All margins were clear of tumors, with the nearest margin being $1.5 \mathrm{~cm}$. One patient had a recurrence. No donor-site morbidity was recorded in any of the patients.

In conclusion, a multidisciplinary approach provides improved outcomes in the management of large dermato-fibro-sarcomas of the chest wall. With this approach, extensive dissection of the tumor is achieved, and reconstruction is performed with minimal complication.
\end{abstract}

\section{Introduction}

Dermato-fibro-sarcomas are locally aggressive tumors with an incidence of four in one million individuals in the USA. ${ }^{1}$ Surgery is the mainstay of treatment. ${ }^{2,3}$ The tumor is prone to high-recurrence rates of 60 percent as recorded in other studies. ${ }^{1-3}$ The main determinants of recurrence are involvement in either deep or lateral margins. ${ }^{4,5}$ Larger excision of chest wall tumors results in large defects with the exposure of the thoracic viscera $(\boldsymbol{- F i g}$. $\mathbf{1})$. We reviewed cases of patients managed by a multidisciplinary team over a duration of 5 years. These patients had extensive chest wall tumors that were resected and reconstructed in a one-staged surgical procedure.

\section{Patients and Methods}

We prospectively reviewed cases of patients managed for dermato-fibro-sarcoma involving the chest wall in

published online August 202020
DOI https://doi.org/

$10.1055 / \mathrm{s}-0040-1714975$ ISSN 0970-0358. various Hospitals in Nairobi, Kenya, between January 2012 and December 2017. Consent for the study was sought from the local ethics board. All patients with histologically confirmed cases of dermato-fibro-sarcoma protuberans during the study period were managed by a multidisciplinary team comprising cardiothoracic surgeons, plastic surgeons, radio-oncologists, pathologists, and counsellors. A treatment plan was drafted by the team and was followed throughout the period. During surgery, the size of the defect and the reconstruction technic utilized were noted. The status of the margin and complication was noted. All patients were subjected to postoperative radiotherapy of at least 60 grays. Postoperative follow-up was at a regular interval for at least 3 years.

\section{Results}

A total of 12 patients with histologically confirmed cases of dermato-fibro-sarcoma protuberans involving the chest

(C) 2020. Association of Plastic Surgeons of India.

This is an open access article published by Thieme under the terms of the Creative Commons Attribution-NonDerivative-NonCommercial-License, permitting copying and reproduction so long as the original work is given appropriate credit. Contents may not be used for commercial purposes, or adapted, remixed, transformed or built upon. (https://creativecommons.org/licenses/by-nc-nd/4.0/).

Thieme Medical and Scientific Publishers Pvt. Ltd. A-12, 2nd Floor, Sector 2, Noida-201301 UP, India 
wall were managed. The age range was 25 to 54 years with a median age of 35.6 years. The male to female ratio was $3: 1$. The defect ranged from $84 \mathrm{~cm}^{2}$ to $270 \mathrm{~cm} 2$ with a mean of $154 \mathrm{~cm} 2$. Soft-tissue reconstruction was done by local, regional and free flaps with latissimus dorsi. Skeletal reconstruction was done with Proline mesh in combination with methyl acrylate cement in seven patients. - Table $\mathbf{1}$ summarizes anatomical location, size of the defect skeletal and soft-tissue reconstructive options utilized. Complications encountered were one free flap loss and tumor recurrence in one patient.

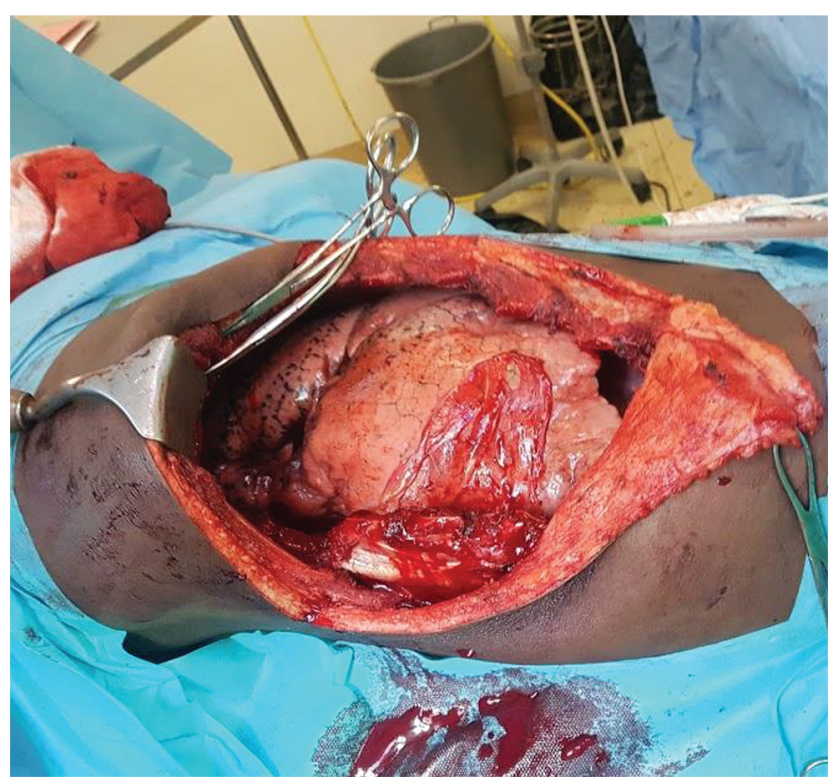

Fig. 1 Huge defect after excision of dermato-fibro-sarcoma of chest wall; six ribs were excised

\section{Discussion}

Dermato-fibro-sarcoma protuberans are locally aggressive tumors that are complex. These tumors have been associated with a higher recurrence rate. ${ }^{1-3}$ Wide local excision with free margins or Moh's micrographic surgeries have been shown to be the best management procedures. ${ }^{3,4}$ Wide excision however transforms into wider defects requiring reconstruction of both skeletal and soft-tissue components of the chest (-Figs. 2-6). The best way to manage this as demonstrated in our series and other studies is through a multidisciplinary approach. $^{5}$

Our patients had a mean surface area of $154 \mathrm{~cm}^{2}$ with a range of 84 to $270 \mathrm{~cm}^{2}$, a maximum of six ribs, and an average of three ribs excised (-Fig. 2). All except three patients required both skeletal and soft-tissue reconstructions. The most commonly utilized skeletal reconstruction procedures in our series were methyl acrylic cement and Proline mesh. To improve the mesh strength and stability, we folded it on itself four times (-Fig. 3 ). In patients who had very wide or extensive defects, we sandwiched the mesh with bone cement. Although inferior to the other bony reconstructive options, we were able to obtain good results with stable and functional reconstruction of the chest wall. None of our patients had paradoxical chest movement, and all of them had good functional outcomes.

Soft-tissue reconstruction in our series was a combination of both local regional and free flaps, with latissimus dorsi muscle and anterolateral thigh (ALT) flaps (-Figs. 3-5). All our flaps were successful except for one patient with who we lost a free flap. With flaps, we were able to provide adequate soft tissue to fill any dead space as well as vascularized tissue to cover the skeletal framework. The flaps utilized were probably still the most commonly used., ${ }^{6,7}$

Table 1 The patients, operations, and reconstructions done

\begin{tabular}{|l|l|l|l|l|}
\hline $\begin{array}{l}\text { Patients age } \\
\text { (years) }\end{array}$ & $\begin{array}{l}\text { Anatomical location of } \\
\text { the tumor }\end{array}$ & $\begin{array}{l}\text { Size of the } \\
\text { defect }\left(\mathbf{c m}^{2}\right)\end{array}$ & Skeletal reconstruction & Soft-tissue reconstruction \\
\hline 25 & Anterior chest & 90 & None & Pedicled latissimus dorsi \\
\hline 28 & Anterior chest & 152 & $\begin{array}{l}\text { Proline mesh with methyl } \\
\text { acrylate acid }\end{array}$ & Latissimus dorsi muscle \\
\hline 33 & Anterior lateral wall & 94 & Proline mesh & Pedicled latissimus dorsi \\
\hline 44 & Right lateral wall & 180 & $\begin{array}{l}\text { Proline mesh + methyl acrylate } \\
\text { acid }\end{array}$ & Free ALT flap \\
\hline 54 & Anterior chest & 168 & $\begin{array}{l}\text { Proline mesh +reconstructive } \\
\text { plate }\end{array}$ & Pedicle TRAM \\
\hline 47 & Anterior lateral chest wall & 195 & $\begin{array}{l}\text { Proline + methyl acrylate } \\
\text { cement }\end{array}$ & Omental + parascapular \\
\hline 35 & Right anterior wall & 98 & $\begin{array}{l}\text { Proline mesh + methyl acrylate } \\
\text { acid }\end{array}$ & Free TRAM flap \\
\hline 42 & Left anterior lateral wall & 192 & Proline mesh + titanium mesh & Free ALT flap \\
\hline 36 & Right anterior chest & 180 & Proline mesh & Omental flap \\
\hline 49 & Posterior thoracic defect & 84 & None & Trapezius muscle flap \\
\hline 60 & $\begin{array}{l}\text { Ant lateral } \\
\text { Chest defect }\end{array}$ & 154 & Proline mesh & $\begin{array}{l}\text { Latissimus dorsi } \\
\text { Muscle flap }\end{array}$ \\
\hline 45 & 270 & Pedicled latissimus dorsi flap \\
\hline
\end{tabular}

Abbreviations: ALT, anterolateral thigh; TRAM, transverse rectus abdominis. 


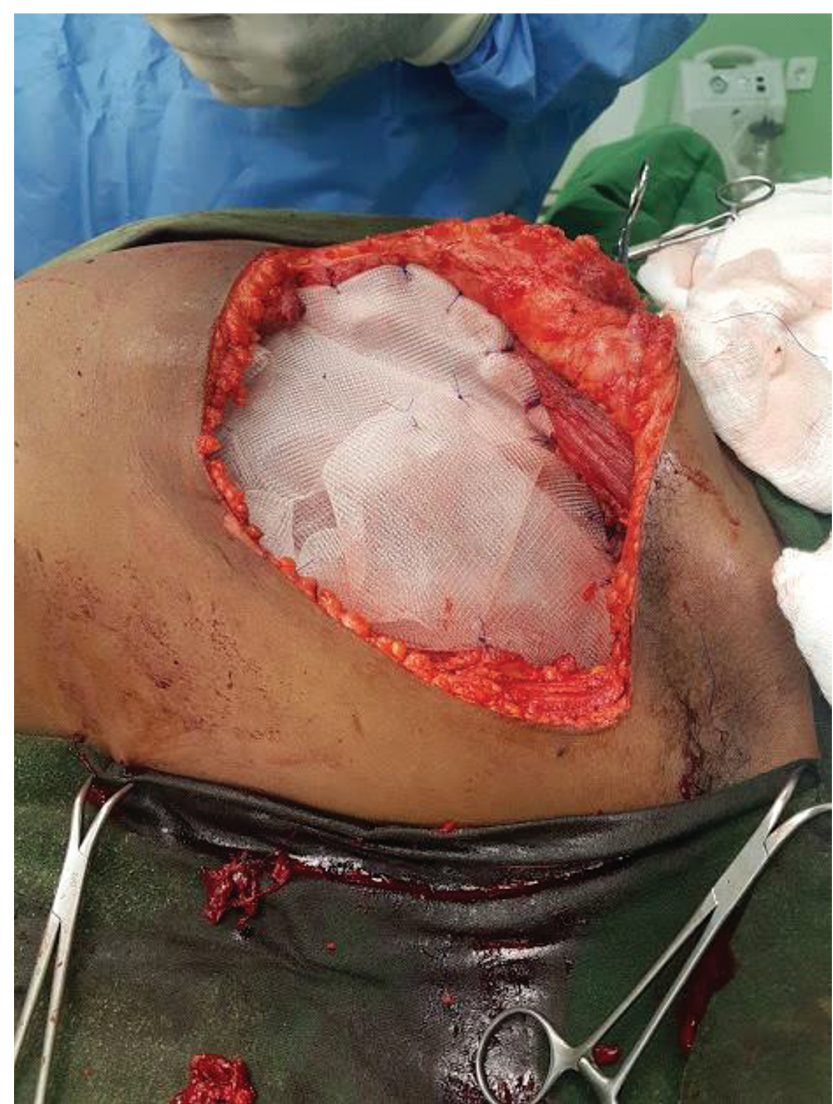

Fig. 2 Thoracic skeletal defect reconstructed with multiple layers of Proline mesh.

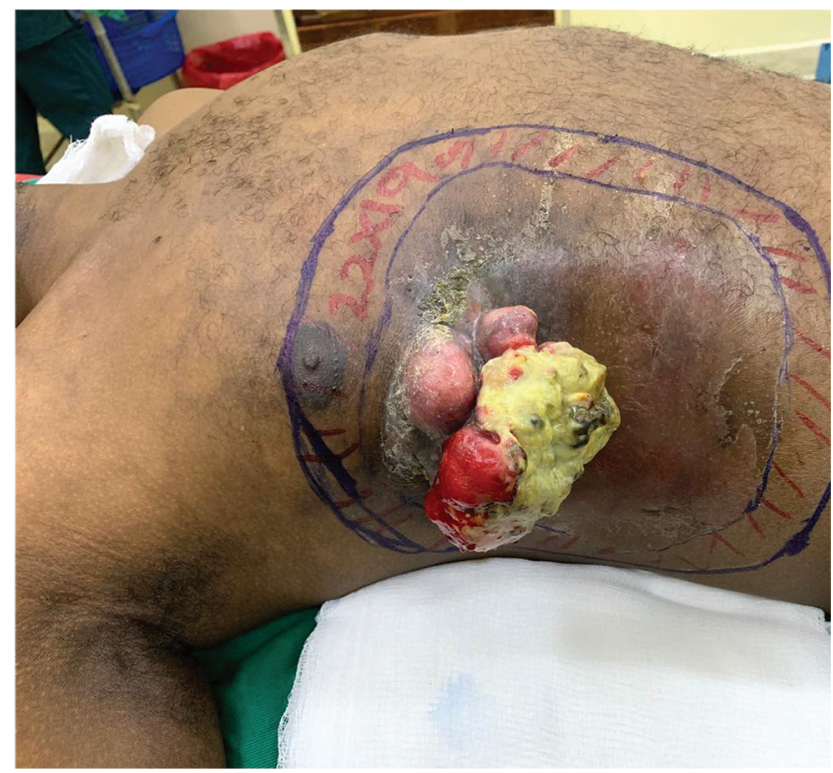

Fig.3 Extensiverightanteriorlateralchestwall dermato-fibro-sarcoma prior to surgical excision marked

Low-recurrence rates, less complication, and better survival rates demonstrated in our series could be attributed to wide oncological reconstruction of the tumors as well as appropriate methods in wound closure. All our resection margins were negative with the nearest being $1.5 \mathrm{~cm}$ from the

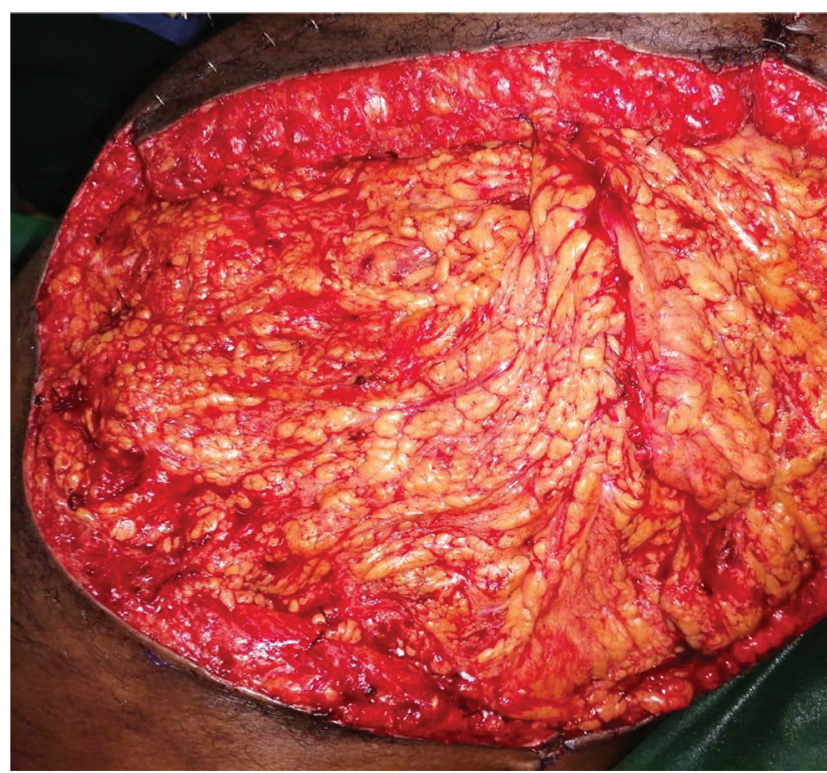

Fig. 4 Defects in Fig. 3 successfully covered with pedicle omental flap.

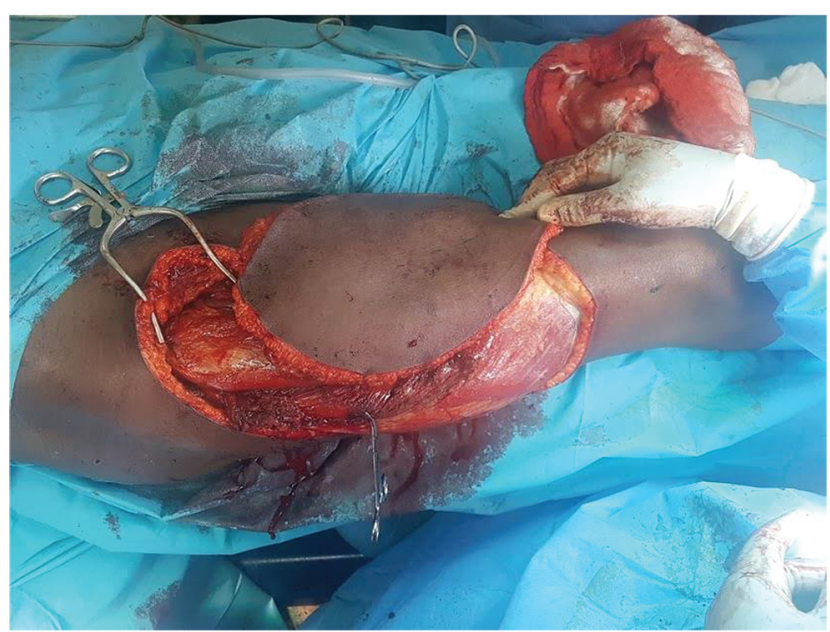

Fig. 5 Anterolateral thigh (ALT) flap being raised to be used for the reconstruction of a thoracic defect.

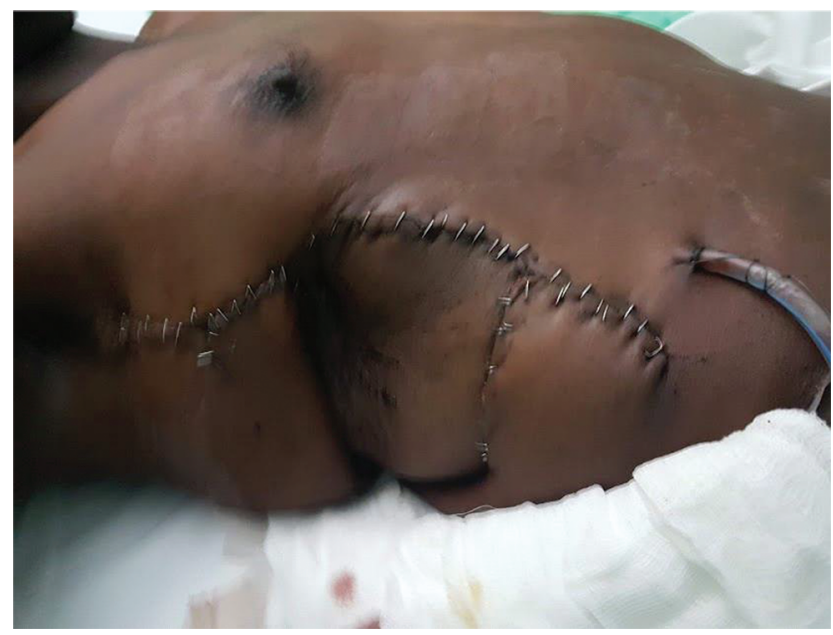

Fig. 6 Right lateral thoracic defects fully closed with methyl acrylate cement and a free anterolateral thigh (ALT) flap at 1 week of follow-up. 
tumor margins. Postexcision, all our patients were subjected to postexcision radiotherapy that has demonstrated to reduce dermato-fibro-sarcoma protuberans recurrence. ${ }^{8}$

\section{Conclusion}

A multidisciplinary approach in the management of chest wall dermato-fibro-sarcoma protuberans tumors reduces overall mortality and morbidity. With this approach, tumors that would have been considered inoperable can be safely excised and reconstructed ( - Fig. 5). Wider resection margins are easily achieved, which ensures complete excision of the tumor and hence lowers recurrence rates. Various skeletal and soft-tissue reconstruction options can then be utilized in covering the defects.

\section{Note}

This article was presented at the Kenya Society of Plastic Surgeons Meeting, $5^{\mathrm{TH}}$ August 2019, Mombasa.

\section{Conflicts of Interest}

None declared.

\section{References}

1 Kreicher KL, Kurlander DE, Gittleman HR, BarnholtzSloan JS, Bordeaux JS. Incidence and survival of primary dermatofibrosarcoma protuberans in the United States. Dermatol Surg 2016;42(Suppl 1) :S24-S31

2 Kim BJ, Kim H, Ji US, et al. Wide local excision for dermato-fibro-sarcoma protuberans: a single-center series of 90 patients. J Cancer 2017;8(7):1319-1323

3 Lowe GC, Onajin O, Baum CL, et al. A comparison of Mohs micrographic surgery and wide local excision for treatment of dermatofibrosarcoma protuberans with long-term follow-up: The Mayo Clinic experience. Dermatol Surg 2017;43(1):98-106

4 Fields RC, Hameed M, Qin LX, et al. Dermatofibrosarcoma protuberans (DFSP): predictors of recurrence and the use of systemic therapy. Ann Surg Oncol 2011;18(2):328-336

5 DuBay D, Cimmino V, Lowe L, Johnson TM, Sondak VK. Low recurrence rate after surgery for dermatofibrosarcoma protuberans: a multidisciplinary approach from a single institution. Cancer 2004;100(5):1008-1016

6 Sanna S, Brandolini J, Pardolesi A, et al. Materials and techniques in chest wall reconstruction: a review. J Vis Surg 2017;3:95

7 Foroulis CN, Kleontas AD, Tagarakis G, et al. Massive chest wall resection and reconstruction for malignant disease. OncoTargets Ther 2016;9:2349-2358

8 Chen Y-T, Tu W-T, Lee W-R, Huang YC. The efficacy of adjuvant radiotherapy in dermatofibrosarcoma protuberans: a systemic review and meta-analysis. J Eur Acad Dermatol Venereol 2016;30(7):1107-1114 